\title{
Relationship between simultaneous exposure to ergonomic risk factors and work-related lower back pain: a cross- sectional study based on the fourth Korean working conditions survey
}

Jae-Yeop Kim, Ji-Su Shin, Myeong-Seob Lim, Hyeon-Gyeong Choi, Sung-Kyeong Kim, Hee-Tae Kang, Sang-Baek Koh and Sung-Soo Oh ${ }^{*}$

\begin{abstract}
Background: It is well known that ergonomic risk factors and back pain are related. However, few studies have examined the relationship between simultaneous exposure to these risk factors and back pain in a Korean population. We aimed to investigate the relationship between simultaneous exposure to ergonomic risk factors and work-related lower back pain (LBP) based on the fourth Korean Working Conditions Survey (KWCS).

Method: The fourth KWCS (2014) was used for this study. Chi-square tests and logistic regression were used to assess relationship between 5 ergonomic risk factors and work-related LBP. We also analyzed the relationship between simultaneous exposure to 2 risk factors and work-related LBP.

Results: All 5 ergonomic risk factors (fatigue-inducing and painful posture; lifting or moving people; dragging, pushing, or moving heavy objects; standing posture; and repetitive hand or arm movements) were significantly correlated with work-related LBP in the severe exposure group (adjusted odd ratios [aOR] 5.09, 95\% confidence interval [Cl] 4.46-5.83; aOR 1.98, 95\% Cl 1.62-2.42; aOR 2.09, 95\% Cl 1.82-2.40; aOR 1.79, 95\% Cl 1.60-2.01; aOR 2.04, $95 \% \mathrm{Cl} 1.82-2.30$, respectively). When exposed to 2 risk factors simultaneously, the relationship between exposure and work-related LBP was not greater than exposure to only 1 risk factor in our study (usually exposed to 'fatigueinducing or painful posture' aOR 2.17, 95\% Cl 2.02-2.34; high exposure to both 'fatigue-inducing or painful posture' and 'dragging, pushing, or moving heavy objects' aOR 2.00, 95\% Cl 1.82-2.20).
\end{abstract}

Conclusions: There was a strong relationship between severe exposure to each ergonomic risk factor and workrelated LBP. However, when exposed to 2 ergonomic risk factors simultaneously, the relationship between exposure and work-related LBP was not stronger than when exposed to only 1 risk factor in our study.

Keywords: Work-related low back pain, Ergonomic risk factors, Simultaneous exposure, Fourth Korean working conditions survey (KWCS)

\footnotetext{
* Correspondence: oss0609@yonsei.ac.kr

Department of Occupational and Environmental Medicine, Wonju Severance

Christian Hospital, Wonju College of Medicine, Yonsei University, Wonju,

South Korea
}

(c) The Author(s). 2018 Open Access This article is distributed under the terms of the Creative Commons Attribution 4.0 International License (http://creativecommons.org/licenses/by/4.0/), which permits unrestricted use, distribution, and reproduction in any medium, provided you give appropriate credit to the original author(s) and the source, provide a link to the Creative Commons license, and indicate if changes were made. The Creative Commons Public Domain Dedication waiver (http://creativecommons.org/publicdomain/zero/1.0/) applies to the data made available in this article, unless otherwise stated. 


\section{Background}

Work-related musculoskeletal disorder (WMSD) is an important health issue worldwide. In multiple countries, musculoskeletal disorders account for the majority of work-related disorders [1, 2], and it is well documented that WMSD incurs substantial social costs $[3,4]$. In South Korea, WMSD accounted for $65.8 \%$ of all work-related disorders in 2016 [5].

Multiple studies have reported that exposure to ergonomic risk factors induces or worsens musculoskeletal disorders [6-8]. Fatigue-inducing or painful posture, repetitive hand or arm movements, prolonged standing or sitting, and inflicting excessive force are examples of ergonomic risk factors [9]. WMSD develops over time, and do not occur as a result of sudden or temporary events [10]. There have been several studies investigating possible approaches to reducing exposure to these ergonomic factors [11-13]. WMSD has been a topic of considerable research interest in Korea since the 1960s [14], with the majority of studies conducted within occupation-specific workplaces [15-19].

It is well known that ergonomic risk factors showed a significant association with LBP [20, 21]. In previous epidemiological studies, back pain has been known to have a strong association with lifting, forceful movement and wholebody vibrations, and a significant association with awkward posture and heavy physical work. In the 1997, the report of the National Institute for Occupational Safety and Health of USA have shown that there were few combined effects of these risk factors on LBP [22]. However, several studies suggested that both lifting and awkward postures were important contributors to the risk of LBP [22]. It is expected that a risk factor (e.g., forceful exertion) in the presence of another risk factor (e.g., repetitive work) or factors (e.g., high repetition in an awkward posture) will interact resulting on WMSD precipitation [9], even though definite multipliers for the interactions still needs to be defined [23]. However, there have been few epidemiological studies investigating relationship between simultaneous exposure to ergonomic risk factors and work-related LBP.

This study analyzed the relationship between ergonomic risk factors and work-related LBP. Particularly, we wanted to investigate the relationship between the simultaneous exposure to these risk factors and LBP, utilizing data from the fourth Korean Working Conditions Survey (KWCS).

\section{Methods}

\section{Participants}

This study utilized data from the fourth KWCS, conducted by the Korea Occupational Safety and Health Agency (KOSHA) in 2014. The KWCS is administered to working individuals aged $\geq 15$ years through household visits and interviews. A total of 50,007 people participated in the fourth KWCS. The reliability and validity of the KWCS has already been established [24].

Individuals with missing values for major variables and covariates were excluded from the analysis. In addition, individuals with responses that were marked, "I don't know or no answer" or "refuse to answer" were also excluded. Who were soldiers or who had an employment status of "unpaid family work" or "other work" were excluded due to a small number of such cases. Finally, 9255 were excluded from the analysis and a total of 40,752 participants were included in the analysis.

\section{Major variables}

To ensure that only work-related LBP were included, only people who responded with "lower back pain" to the question "Have you had the following health problems in the past 12 months?" and answered "yes" to the additional question "If you had, did it result from your work?" were considered as having work-related LBP. Individuals who responded with "I don't know/no answer" or "refuse to answer" were excluded from the analysis.

All 5 ergonomic risk factors included in the fourth KWCS survey were included in the analysis. The risk factors were: "fatigue-inducing or painful posture," "lifting or moving people," "dragging, pushing, or moving heavy objects," "standing posture," and "repetitive hand or arm movements." There were 7 levels of exposure to each risk factors (no exposure at all, hardly any exposure, $1 / 4$ of the working hour, $1 / 2$ of the working hour, $3 / 4$ of the working hour, almost the entire working hour, and the entire working hour). Based on survey results, exposure to risk factors was reclassified into 4 categories: none, mild, moderate, and severe. 'No exposure at all' was classified as none, 'hardly any exposure at all' and '1/ 4 of the working hour' were classified as mild exposure, ' $1 / 2$ of the working hour' and ' $3 / 4$ of the working hour' considered moderate exposure, and 'almost the entire working hour' and 'the entire working hour' were classified as severe exposure.

\section{Covariates}

Potential confounding variables included sex, age, occupational class, type of employment, working hours, shift work, number of employees in the workplace, level of education, income, autonomy in taking breaks during work, and vibration exposure. Age was divided into 5 groups: under 30, 30-39 years, 40-49 years, 50-59 years, and above 60 years. Based on the Korean Standard Occupational Classification (6th revision) [25], the KWCS data investigated 10 occupation types, and also surveyed soldiers. Occupation was classified into 3 categories: white collar (managers, professionals, technicians and semi-experts, and office workers), service workers 
(service workers and sales workers), and blue collar (skilled agricultural and fishery workers, functional operators and relevant functional workers, equipment, machinery handlers and assembly workers, and simple laborers).

Nonpaid family workers and other workers were excluded from the analysis due to small sample size, resulting in 3 types of included employment: self-employed without employees, self-employed with employees, and paid workers. Working hours were classified into 3 groups: under $40 \mathrm{~h}$ per week, $40-60 \mathrm{~h}$ per week, and greater than $60 \mathrm{~h}$ per week. The number of employees in the workplace was divided into 4 groups: under 5, 5$49,50-299$, and more than 300.

Autonomy with taking breaks during work was examined with the question, "Can you take a break when you want?" to which 5 responses were possible: always, most of the time, sometimes, not really, and not at all. These responses were then clustered into 3 categories: "always" and "most of the time" were grouped into "mostly," "sometimes" and "not really" were grouped into "sometimes," and "not at all" was grouped into "never."

Vibration exposure was assessed with the question, "How much are you exposed to hand-transmitted vibration or vibration generated by machinery?" 7 responses were possible: no exposure at all, hardly any exposure, $1 / 4$ of the working hour, $1 / 2$ of the working hour, $3 / 4$ of the working hour, nearly the entire working hour, and the entire working hour. These were then clustered into 4 groups, as follows: "No exposure at all" was reclassified as "never," "hardly any exposure" or " $1 / 4$ of the working hour" into "mild," " $1 / 2$ of the working hour" or " $3 / 4$ of the working hour" into "moderate," and "nearly the entire working hour" or "entire working hour" into "severe."

\section{Analysis}

The chi-square test was used to examine the general characteristics of the study population with regarding to the work-related LBP and trend test was also conducted. Relationship between the 5 ergonomic risk factors and work-related LBP were examined using logistic regression. Analyses were performed after adjusting for sex, age, occupational classification, type of employment, working hours, shift work, number of employees in workplace, education, income, autonomy of taking breaks during work, and vibration exposure.

The relationship between simultaneous exposure to ergonomic risk factors and work-related LBP was examined using logistic regression. Exposure to 2 risk factors was classified into 4 groups according to Table 1.

Compared to group 1, relationships between groups 2, 3 , and 4 and lower back symptoms were analyzed with logistic regression (Table 1). Sex, age, occupation, type of employment, working hours, shift work, number of employees in workplace, education, income, autonomy of taking breaks during work, and vibration exposure were adjusted for. After selecting 2 risk factors (A and B in Table 1) to analyze the effects of simultaneous exposure, we also adjusted for the remaining 3 ergonomic risk factors.

The data were analyzed using the IBM SPSS 23.0 software (Chicago, IL, USA).

\section{Results}

The general characteristics of participants are shown in Table 2. From a total of 40,752 participants included in the final analysis, 21,462 were male and 19,290 were female. With the exception of shift work, there were significant differences in the prevalence of work-related LBP across groups for all variables. The prevalence of work-related LBP was higher in self-employed individuals with no employees than in paid workers, and symptoms were found to increase with a decreasing number of employees in the workplace. Work-related LBP were found to increase with higher exposure to each ergonomic risk factors, except 'lifting or moving people'.

Relationship between the degree of exposure to each risk factor and work-related LBP are shown in Table 3. For 'fatigue-inducing or painful posture,' 'dragging, pushing, or moving heavy objects', 'standing posture' and 'repetitive hand or arm movements' risk factors, the relationship between exposure and work-related LBP increased with increasing severity of exposure, compared to the no exposure group, regardless of adjustment. For the 'lifting or moving people' risk factor, the mild and moderate exposure groups tended to have less LBP than the exposed groups (adjusted OR [aOR] 0.82, 95\% confidence interval [CI] $0.77-0.88$; aOR $0.78,95 \%$ CI $0.68-$ 0.89 , respectively). However, the severe exposure group

Table 1 Classification for simultaneous exposure to 2 ergonomic risk factors

\begin{tabular}{|c|c|c|c|c|c|}
\hline & & \multicolumn{4}{|c|}{ Ergonomic risk factors $\mathrm{A}$} \\
\hline & & Never & Mild & Moderate & Severe \\
\hline \multirow[t]{4}{*}{ Ergonomic risk factors $B$} & Never & \multirow{2}{*}{\multicolumn{2}{|c|}{ 1. Little exposure to $A, B$}} & \multicolumn{2}{|c|}{ 2. Usually exposed to A } \\
\hline & Mild & & & & \\
\hline & Moderate & \multicolumn{2}{|c|}{ 3. Usually exposed to $B$} & \multicolumn{2}{|c|}{ 4. High exposure to $A, B$} \\
\hline & Severe & & & & \\
\hline
\end{tabular}


Table 2 Demographic and exposure characteristics of the study population

\begin{tabular}{|c|c|c|c|}
\hline \multirow[b]{2}{*}{ Total $(n=40,752)$} & \multicolumn{3}{|c|}{ Work-related LBP } \\
\hline & Yes $(n, \%)$ & No $(n, \%)$ & $p$-value \\
\hline Sex & & & $<0.001$ \\
\hline Male & $2815(13.1)$ & $18,647(86.9)$ & \\
\hline Female & $3221(16.7)$ & $16,069(83.3)$ & \\
\hline Age & & & $<0.001$ \\
\hline$<30$ & $257(6.2)$ & $3896(93.8)$ & \\
\hline $30-39$ & $740(9.1)$ & $7312(90.9)$ & \\
\hline $40-49$ & $1425(12.8)$ & $9669(87.2)$ & \\
\hline $50-59$ & $1513(16.2)$ & $7804(83.8)$ & \\
\hline$\geq 60$ & $2101(26.0)$ & $5975(74.0)$ & \\
\hline Occupation type & & & $<0.001$ \\
\hline White collar & $890(7.0)$ & $11,819(93.0)$ & \\
\hline Service workers & $1862(13.5)$ & $11,950(86.5)$ & \\
\hline Blue collar & $3284(23.1)$ & $10,947(76.9)$ & \\
\hline Employment status & & & $<0.001$ \\
\hline Self-employed without employees & $2510(23.7)$ & $8103(76.3)$ & \\
\hline Self-employed with employees & $312(13.1)$ & $2077(86.9)$ & \\
\hline Paid workers & $3214(11.6)$ & $24,536(88.4)$ & \\
\hline Working hours (/week) & & & $<0.001$ \\
\hline$<40$ & $1370(20.7)$ & $5243(79.3)$ & \\
\hline $40-59$ & $2953(12.0)$ & $21,736(88.0)$ & \\
\hline$\geq 60$ & $1713(18.1)$ & $7737(81.9)$ & \\
\hline Shift work & & & 0.578 \\
\hline Yes & $445(14.5)$ & $2634(85.5)$ & \\
\hline No & $5591(14.8)$ & $32,082(85.2)$ & \\
\hline Number of employees & & & $<0.001$ \\
\hline$<5$ & $3619(19.3)$ & $15,088(80.7)$ & \\
\hline $5-49$ & $1656(11.2)$ & $13,081(88.8)$ & \\
\hline $50-299$ & $537(10.7)$ & $4504(89.3)$ & \\
\hline$\geq 300$ & $224(9.9)$ & $2043(90.1)$ & \\
\hline Education & & & $<0.001$ \\
\hline Below elementary & $1348(32.6)$ & $2786(67.4)$ & \\
\hline Middle \& high school & $3298(16.6)$ & $16,537(83.4)$ & \\
\hline Above university & $1390(8.3)$ & $15,393(91.7)$ & \\
\hline Income (10,000 /month) & & & $<0.001$ \\
\hline$<100$ & $1580(23.6)$ & $5127(76.4)$ & \\
\hline 100-199 & $2138(15.8)$ & $11,429(84.2)$ & \\
\hline 200-399 & $1898(11.6)$ & $14,454(88.4)$ & \\
\hline$\geq 400$ & $420(10.2)$ & 3706 (89.8) & \\
\hline Rest during work time & & & $<0.001$ \\
\hline Always \& most & $2250(16.4)$ & $11,428(83.6)$ & \\
\hline Sometimes & $3389(13.6)$ & $21,611(86.4)$ & \\
\hline Never & $397(19.1)$ & $1677(80.9)$ & \\
\hline Vibration exposure & & & $<0.001$ \\
\hline
\end{tabular}


Table 2 Demographic and exposure characteristics of the study population (Continued)

\begin{tabular}{|c|c|c|c|}
\hline \multirow[b]{2}{*}{ Total $(n=40,752)$} & \multicolumn{3}{|c|}{ Work-related LBP } \\
\hline & Yes $(n, \%)$ & No $(n, \%)$ & $p$-value \\
\hline None & $2164(11.8)$ & $16,180(88.2)$ & \\
\hline Mild & $2785(16.9)$ & $13,653(83.1)$ & \\
\hline Moderate & $665(16.9)$ & $3268(83.1)$ & \\
\hline Severe & $422(20.7)$ & $1615(79.3)$ & \\
\hline Fatiguing or painful posture & & & $<0.001$ \\
\hline None & $386(5.5)$ & $6575(94.5)$ & \\
\hline Mild & $2436(11.8)$ & $18,191(88.2)$ & \\
\hline Moderate & $2077(21.7)$ & $7499(78.3)$ & \\
\hline Severe & $1137(31.7)$ & $2451(68.3)$ & \\
\hline Lifting or moving people & & & $<0.001$ \\
\hline None & $3548(15.1)$ & $20,004(84.9)$ & \\
\hline Mild & $2042(13.8)$ & $12,727(86.2)$ & \\
\hline Moderate & $285(14.9)$ & $1630(85.1)$ & \\
\hline Severe & $161(31.2)$ & $355(68.8)$ & \\
\hline Dragging, pushing, or moving heavy objects & & & $<0.001$ \\
\hline None & $986(8.8)$ & $10,202(91.2)$ & \\
\hline Mild & $3334(15.5)$ & $18,217(84.5)$ & \\
\hline Moderate & $1291(20.6)$ & $4982(79.4)$ & \\
\hline Severe & $425(24.4)$ & $1315(75.6)$ & \\
\hline Standing posture & & & $<0.001$ \\
\hline None & $577(9.2)$ & $5665(90.8)$ & \\
\hline Mild & $2108(12.9)$ & $14,202(87.1)$ & \\
\hline Moderate & $2006(17.1)$ & $9694(82.9)$ & \\
\hline Severe & $1345(20.7)$ & $5155(79.3)$ & \\
\hline Repetitive hand or arm movements & & & $<0.001$ \\
\hline None & $448(8.0)$ & $5148(92.0)$ & \\
\hline Mild & $1562(11.4)$ & $12,187(88.6)$ & \\
\hline Moderate & $2061(17.0)$ & $10,066(83.0)$ & \\
\hline Severe & $1965(21.2)$ & $7315(78.8)$ & \\
\hline
\end{tabular}

Abbreviations: $L B P$ lower back pain

Test for trend was conducted for all variable except 'shift work'

showed a correlation with work-related LBP (aOR 1.98, 95\% CI 1.62-2.42).

The relationship between simultaneous exposure to 2 ergonomic risk factors (Table 1) and prevalence of work-related LBP was analyzed using logistic regression (Tables 4, 5 and 6). Compared to the group with low exposure to 2 risk factors, usually being exposed to 1 risk factor was a relationship with work-related LBP. However, the relationship between high exposure to 2 risk factors and work-related LBP did not increase when comparing exposure to only 1 risk factors. Usually exposed group to 'fatigue-inducing or painful posture' (aOR 2.17, 95\% CI 2.02-2.34) and high exposed group to both 'fatigue-inducing or painful posture' and 'dragging, pushing, or moving heavy objects' (aOR 2.00, 95\% CI 1.82-2.20) had similar adjusted odd ratio (Table 4). Table 5 (between 'fatigue-inducing or painful posture' and 'repetitive hand or arm movements') and Table 6 ('repetitive hand or arm movements' and 'dragging, pushing, or moving heavy objects') had similar result with Table 4.

\section{Discussion}

This study analyzed relationship between ergonomic risk factors and work-related LBP in Koreans, using large-scale survey data. The prevalence of work-related LBP increased with age, and was higher in blue-collar occupations than in white-collar occupations. Interestingly, the prevalence 
Table 3 Logistic regression analysis for ergonomic risk-factor exposure and work-related LBP

\begin{tabular}{|c|c|c|}
\hline \multirow[b]{2}{*}{ Ergonomic risk factor } & \multicolumn{2}{|l|}{ Work-related LBP } \\
\hline & Crude & Adjusted $^{a}$ \\
\hline \multicolumn{3}{|c|}{ Fatigue-inducing or painful posture } \\
\hline None & (ref) & (ref) \\
\hline Mild & $2.28(2.04-2.54)^{*}$ & $1.86(1.65-2.08)^{*}$ \\
\hline Moderate & $4.71(4.21-5.28)^{*}$ & $3.27(2.89-3.69)^{*}$ \\
\hline Severe & $7.90(6.97-8.94)^{*}$ & $5.09(4.46-5.83)^{*}$ \\
\hline \multicolumn{3}{|c|}{ Lifting or moving people } \\
\hline None & (ref) & (ref) \\
\hline Mild & $0.90(0.85-0.95)^{* *}$ & $0.82(0.77-0.88)^{*}$ \\
\hline Moderate & $0.98(0.86-1.12)$ & $0.78(0.68-0.89)^{*}$ \\
\hline Severe & $2.55(2.11-3.09)^{*}$ & $1.98(1.62-2.42)^{*}$ \\
\hline \multicolumn{3}{|c|}{ Dragging, pushing, or moving heavy objects } \\
\hline None & (ref) & (ref) \\
\hline Mild & $1.89(1.76-2.04)^{*}$ & $1.38(1.27-1.50)^{*}$ \\
\hline Moderate & $2.68(2.45-2.93)^{*}$ & $1.64(1.49-1.82)^{*}$ \\
\hline Severe & $3.34(2.94-3.79)^{*}$ & $2.09(1.82-2.40)^{*}$ \\
\hline \multicolumn{3}{|l|}{ Standing posture } \\
\hline None & (ref) & (ref) \\
\hline Mild & $1.45(1.32-1.60)^{*}$ & $1.09(0.98-1.20)$ \\
\hline Moderate & $2.03(1.84-2.24)^{*}$ & $1.35(1.21-1.50)^{*}$ \\
\hline Severe & $2.56(2.30-2.84)^{*}$ & $1.79(1.60-2.01)^{*}$ \\
\hline \multicolumn{3}{|c|}{ Repetitive hand or arm movements } \\
\hline None & (ref) & (ref) \\
\hline Mild & $1.47(1.31-1.64)^{*}$ & $1.23(1.10-1.38)^{*}$ \\
\hline Moderate & $2.35(2.11-2.62)^{*}$ & $1.69(1.51-1.90)^{*}$ \\
\hline Severe & $3.08(2.76-3.44)^{*}$ & $2.04(1.82-2.30)^{*}$ \\
\hline
\end{tabular}

Abbreviations: LBP lower back pain

Data presented as odds ratios and $95 \%$ confidence intervals

${ }^{a}$ Adjusted for sex, age, occupational type, employment status, working hours, shift work, number of employees, education, income, rest during work time, and vibration exposure

${ }^{*} p$-value $<0.001$

${ }^{* *} p$-value $<0.05$ of work-related LBP was higher in self-employed individuals than in paid workers, and the prevalence was higher in self-employed individuals without employees. This suggests that self-employed individuals in Korea are also exposed to ergonomic risk factors and may be at a greater risk of developing work-related LBP. Symptoms were also more prevalent when there was a smaller number of employees in the participant's workplace. This may be due to increased workload requirements or greater exposure to ergonomic risk factors in smaller businesses. In the light of these results, small business owners in agriculture, transportation, or restaurants are exposed similarly to ergonomic risk factors as paid workers are. Thus, future studies that investigate ergonomic risk factors in Koreans should include both small business owners and paid workers.

Work-related LBP were more prevalent in those who were unable to take breaks during work than those who could take breaks as required. Although some studies have found that shift work affects musculoskeletal symptoms [26], we did not find a significant relationship in this study. However, this may be attributable to the fact that we only analyzed whether shift work was performed. Further detailed analysis of shift work might have yielded different results. In our study, the prevalence of work- related lower back symptoms tended to increase with increasing severity of exposure to vibration. However, one of longitudinal studies provided no evidence for the relationship between vibration and low back WMSD [9].

Excluding the risk factor of lifting or moving people, the relationship between exposure and work-related LBP was increased with increasing exposure to each risk factors. In previous study, LBP has a strong correlation with moving or pushing objects and whole-body vibration and has a moderate correlation with fatigue-inducing or painful posture and has a low correlation with standing posture, such as static work posture [22]. Fatigue-inducing or painful posture, as stated in the fourth KWCS, refers to posture

Table 4 Logistic regression analysis for work-related LBP and 2 Ergonomic risk-factors ('Fatigue-inducing or painful posture' and 'Dragging, pushing, or moving heavy objects')

\begin{tabular}{|c|c|c|}
\hline \multirow[b]{2}{*}{ Ergonomic risk exposure } & \multicolumn{2}{|l|}{ Work-related LBP } \\
\hline & Crude & Adjusted $^{a}$ \\
\hline $\begin{array}{l}\text { Little exposure to both 'fatigue-inducing or painful posture' and 'dragging, } \\
\text { pushing, or moving heavy objects' }(n=24,819)\end{array}$ & Reference & Reference \\
\hline Usually exposed to 'fatigue-inducing or painful posture' $(n=7920)$ & $3.01(2.82-3.22)^{*}$ & $2.17(2.02-2.34)^{*}$ \\
\hline Usually exposed to 'dragging, pushing, or moving heavy objects' $(n=2769)$ & $1.72(1.54-1.92)^{*}$ & $1.33(1.19-1.50)^{*}$ \\
\hline $\begin{array}{l}\text { High exposure to both 'fatigue-inducing or painful posture' and 'dragging, } \\
\text { pushing, or moving heavy objects' }(n=5244)\end{array}$ & $3.04(2.82-3.28)^{*}$ & $2.00(1.82-2.20)^{*}$ \\
\hline
\end{tabular}

Abbreviations: $L B P$ lower back pain

Data presented as odds ratios and $95 \%$ confidence intervals

${ }^{a}$ Adjusted for sex, age, occupational type, employment status, working hours, shift work, number of employees, education, income, rest during work time, vibration exposure, 'lifting or moving people', 'standing posture', 'repetitive hand or arm movements'

${ }^{*} p$-value $<0.001$ 
Table 5 Logistic regression analysis for work-related LBP and 2 Ergonomic risk-factors ('Fatigue-inducing or painful posture' and 'Repetitive hand or arm movements')

\begin{tabular}{|c|c|c|}
\hline \multirow[b]{2}{*}{ Ergonomic risk exposure } & \multicolumn{2}{|l|}{ Work-related LBP } \\
\hline & Crude & Adjusted $^{a}$ \\
\hline $\begin{array}{l}\text { Little exposure to both 'fatigue-inducing or painful posture' and 'repetitive } \\
\text { hand and arm movements' }(n=16,713)\end{array}$ & Reference & Reference \\
\hline Usually exposed to 'fatigue-inducing or painful posture' $(n=2632)$ & $2.93(2.63-3.26)^{*}$ & $2.31(2.06-2.60)^{*}$ \\
\hline Usually exposed to 'repetitive hand or arm movements' $(n=10,875)$ & $1.54(1.42-1.67)^{*}$ & $1.30(1.19-1.42)^{*}$ \\
\hline $\begin{array}{l}\text { High exposure to both 'fatigue-inducing or painful postur'e and 'repetitive } \\
\text { hand or arm movements' }(n=10,532)\end{array}$ & $3.55(3.31-3.81)^{*}$ & $2.39(2.19-2.60)^{*}$ \\
\hline
\end{tabular}

Abbreviations: $L B P$ lower back pain

Data presented as odds ratios and $95 \%$ confidence intervals

${ }^{a}$ Adjusted for sex, age, occupational type, employment status, working hours, shift work, number of employees, education, income, rest during work time, vibration exposure, 'lifting or moving people', 'dragging, pushing or moving heavy objects', 'standing posture'

${ }^{*} p$-value $<0.001$

that occurs when looking back or bending the back. This awkward posture was known to be well correlated with LBP [27] and this was also supported by our findings. In our study, work-related LBP was most strongly associated with 'fatigue-inducing or painful posture' risk factor and these awkward postures have been reported to have causal relationship with low back WMSD [9]. There is a theory that suggests that actual internal derangement related to higher mechanical stresses, such as from continually working in an awkward posture, may lead to more disabling forms of LBP. However, the biological plausibility of this theory requires further evidence from additional higher quality studies [28].

Moving people is generally believed to ergonomic risk factor [29-31]. However, interestingly, mild or moderate exposure to 'lifting or moving people' group was tended to have less work-related LBP than the exposed groups and only severe exposure group was strongly correlated with work-related lower back symptoms. As a result of our search, such results have not been reported in previous studies. Compared to the daily frequency of moving or lifting objects, the daily frequency of moving or lifting people may be much lower. Also, mildly engaging in moving or lifting people may serve as a strengthening exercise for the body.

Ergonomic risk factors could be seen as potential factors towards the development of work-related LBP and most studies investigated the combined effect of these factors. We performed additional analysis to investigate whether being simultaneously exposed to 2 ergonomic risk factors increases the relationship with work-related lower back symptoms (Tables 4, 5 and 6). When severely exposed to 2 risk factors, the degree of relationship between exposure and work-related LBP was similar to that when only usually exposed to 1 risk factor. Previous epidemiological studies suggest that there is no combined effect of ergonomic risk factors on back pain, however, elbow and hand/wrist have a combined effect [22]. The similar results were found in our study involving a Korean population. Although combined effect of ergonomic risk factors is less likely to be associated with work-related LBP, another study had shown that simultaneous exposure to inadequate posture and wholebody vibration increases the risk of back pain [22, 32]. In the future, it seems that studies related to the combined effects of ergonomic risk

Table 6 Logistic regression analysis for work-related LBP and 2 Ergonomic risk-factors ('Repetitive hand or arm movements' and 'Dragging, pushing, or moving heavy objects')

\begin{tabular}{|c|c|c|}
\hline \multirow[b]{2}{*}{ Ergonomic risk exposure } & \multicolumn{2}{|l|}{ Work-related LBP } \\
\hline & Crude & Adjusted $^{\mathrm{a}}$ \\
\hline $\begin{array}{l}\text { Little exposure to both 'repetitive hand or arm movements' and 'dragging, pushing, } \\
\text { or moving heavy objects' }(n=17,547)\end{array}$ & Reference & Reference \\
\hline Usually exposed to 'repetitive hand or arm movements' $(n=15,192)$ & $2.00(1.88-2.14)^{*}$ & $1.25(1.15-1.34)^{*}$ \\
\hline Usually exposed to 'dragging, pushing, or moving heavy objects' $(n=1798)$ & $2.21(1.95-2.52)^{*}$ & $1.37(1.19-1.57)^{*}$ \\
\hline $\begin{array}{l}\text { High exposure to both 'repetitive hand or arm movements' and 'dragging, pushing, } \\
\text { or moving heavy objects' }(n=6215)\end{array}$ & $2.70(2.50-2.92)^{*}$ & $1.49(1.39-1.59)^{* *}$ \\
\hline
\end{tabular}

Abbreviations: $L B P$ lower back pain

Data presented as odds ratios and $95 \%$ confidence intervals

${ }^{a}$ Adjusted for sex, age, occupational type, employment status, working hours, shift work, number of employees, education, income, rest during work time,

vibration exposure, 'fatigue-inducing or painful posture', 'lifting or moving people', 'standing posture'

${ }^{*} p$-value $<0.001$

${ }^{* *} p$-value $<0.05$ 
factors for other WMSDs (e.g., elbow) besides back WMSD are needed.

This study has some limitations. First, as the KWCS is a cross-sectional study, only relation between symptoms and risk factors could be established, not causal relationships. Second, although surveyors conducted 1:1 interview, ergonomic risk factors and work-related back pain symptoms were self-reported, rendering them vulnerable to response bias. The use of self-reports as a way of evaluating ergonomic risk factors is known to be imprecise and unreliable [33]. Our study was based on questionnaire so that it could be vulnerable misclassification of both exposure and outcome and it could have recall bias. In addition, although it has been previously reported that WRMDs are highly associated with body mass index (BMI) [34], BMI data was not available in the KWCS. Additionally, although vibration exposure could be divided into whole-body vibration, motion sickness, and hand-transmitted vibration [35], the survey did not include this breakdown of vibration types, potentially introducing error. Previous studies have reported that workers who do not wear personal protection devices are more easily exposed to hazardous factors such as noise or vibration [36], but this study could not adjust for the use of personal protection devices. Additionally, we could not adjust for variables such as job stress or psychosocial work environment, which have also been suggested to ergonomic risk factors [37-39].

Despite these limitations, this study was focused on simultaneous exposure to multiple ergonomic risk factors. In addition, large-scale survey data was used and we analyzed not only paid workers, but also self-employment without employee. Our study suggests that self-employed workers should be included in the study of WMSD in the future.

\section{Conclusions}

There was a strong relationship between severe exposure to each ergonomic risk factors (fatigue-inducing or painful posture; lifting or moving people; dragging, pushing, or moving heavy objects; standing posture; repetitive hand or arm movements) and work-related LBP. When exposed to 2 ergonomic risk factors simultaneously, the relationship between exposure and work-related LBP was not stronger than when exposed to only 1 risk factor in our study. Further studies are needed to investigate the combined effect of ergonomic risk factors to other WMSD (e.g., elbow, hand/wrist).

\section{Abbreviations}

BMI: Body mass index; KOSHA: Korea Occupational Safety and Health Agency; KWCS: Korean Working Conditions Survey; LBP: Lower back pain; WMSD: Work-related musculoskeletal disorder

\section{Acknowledgements}

I would like to thank Safety and Health Policy Research Department (Occupational Safety and Health Research Institute) for offering raw-data from the Korean Working Conditions Survey (KWCS). The paper's contents are solely the responsibility of the author and do not necessarily represent the official views of the OSHRI. I would like to thank Editage

(http://www.editage.co.kr) for English language editing.

\section{Availability of data and materials}

The raw data collected via the Korean Working Conditions Survey and used in the present study were provided by the Safety and Health Policy Research Department (Occupational Safety and Health Research Institute). http:// www.kosha.or.kr/main.do?chk=1

\section{Authors' contributions}

JYK and SSO designed the research, performed statistical analysis, interpreted the data, and wrote the manuscript. JSS, MSL, HKC, SSK, SBK, and HTK critically revised the manuscript. All authors read and approved the final manuscript.

Ethics approval and consent to participate

Not applicable.

\section{Consent for publication}

Not applicable.

\section{Competing interests}

The authors declare that they have no competing interests.

\section{Publisher's Note}

Springer Nature remains neutral with regard to jurisdictional claims in published maps and institutional affiliations.

Received: 8 May 2018 Accepted: 29 August 2018

Published online: 05 September 2018

\section{References}

1. Punnett L, Fine $L$, Keyserling WM, Herrin GD, Chaffin DB. Back disorders and nonneutral trunk postures of automobile assembly workers. Scand J Work Environ Health. 1991;17(5):337-46.

2. Punnett $\mathrm{L}$, Wegman $\mathrm{DH}$. Work-related musculoskeletal disorders: the epidemiologic evidence and the debate. J Electromyogr Kinesiol. 2004;14(1): $13-23$.

3. Buckle P. Ergonomics and musculoskeletal disorders: overview. Occup Med. 2005;55(3):164-7. Evidence-based prevention of work-related musculoskeletal injuries in construction industry

4. Morken T, Riise T, Moen B, Hauge SH, Holien S, Langedrag A, et al. Low back pain and widespread pain predict sickness absence among industrial workers. BMC Musculoskelet Disord. 2003:4:21.

5. Kim YM, Cho SI. Work-life imbalance and musculoskeletal disorders among south Korean workers. Int J Environ Res Public Health. 2017; https://doi.org/ 10.3390/ijerph14111331.

6. Hagberg M. Electromyographic signs of shoulder muscular fatigue in two elevated arm positions. Am J Phys Med. 1981;60(3):111-21.

7. van der Windt DA, Thomas E, Pope DP, de Winter AF, Macfarlane GJ, Bouter LM, et al. Occupational risk factors for shoulder pain: a systematic review. Occup Environ Med. 2000;57(7):433-42.

8. Malchaire J, Cock N, Vergracht S. Review of the factors associated with musculoskeletal problems in epidemiological studies. Int Arch Occup Environ Health. 2001:74(2):79-90.

9. da Costa BR, Vieira ER. Risk factors for work-related musculoskeletal disorders: a systematic review of recent longitudinal studies. Am J Ind Med. 2010;53(3):285-323. https://doi.org/10.1002/ajim.20750.

10. Rwamamara RA, Lagerqvist O, Olofsson T, Johansson BM, Kaminskas KA. Evidence-based prevention of work-related musculoskeletal injuries in construction industry. J Civ Eng. 2010; https://doi.org/10.3846/jcem.2010.56.

11. Major ME, Vézina N. Analysis of worker strategies: a comprehensive understanding for the prevention of work related musculoskeletal disorders. Int J Ind Ergo. 2015; https://doi.org/10.1016/j.ergon.2015.05.003.

12. Oakman J, Chan S. Risk management: where should we target strategies to reduce work-related musculoskeletal disorders? Saf Sci. 2015; https://doi.org/ 10.1016/j.ssci.2014.11.026. 
13. Oakman J, Rothmore P, Tappin D. Intervention development to reduce musculoskeletal disorders: is the process on target? Appl Ergon. 2016; https://doi.org/10.1016/j.apergo.2016.03.019.

14. Kim EA, Nakata M. Work-related musculoskeletal disorders in Korea and Japan: a comparative description. Ann Occup Environ Med. 2014;26(17)

15. Park $\mathrm{CY}$, Cho KH, Lee $\mathrm{SH}$. Cervicobrachial disorders of female international telephone operators I. Subjective symptoms. Korean J Occup Environ Med. 1989;1(2):141-50.

16. Park KY, Bak KJ, Lee JG, Lee YS, Roh JH. Factors affecting the complaints of subjective symptoms in VDT operators. Korean J Occup Environ Med. 1997; 9(1):156-69.

17. Park SK, Choi YJ, Moon DH, Chun JH, Lee JT, Sohn HS. Work related musculoskeletal disorders of hairdresser. Korean J Occup Environ Med. 2000; 12(3):395-404

18. Yun MH, Lee YG, Eoh HJ, Lim SH. Results of a survey on the awareness and severity assessment of upper-limb work-related musculoskeletal disorders among female bank tellers in Korea. Int J Ind Ergo. 2001; https://doi.org/10. 1016/S0169-8141(00)00062-7.

19. Kee D, Seo SR. Musculoskeletal disorders among nursing personnel in Korea. Int J Ind Ergo. 2007; https://doi.org/10.1016/j.ergon.2006.10.020.

20. Alperovitch-Najenson D, Santo Y, Masharawi Y, Katz-Leurer M, Ushvaev D, Kalichman L. Low back pain among professional bus drivers: ergonomic and occupational-psychosocial risk factors. Isr Med Assoc J. 2010;12(1):26-31.

21. Labbafinejad $Y$, Imanizade $Z$, Danesh $\mathrm{H}$. Ergonomic risk factors and their association with lower back and neck pain among pharmaceutical employees in Iran. Workplace Health Saf. 2016;63(12):586-95.

22. Putz-Anderson V, Bernard BP, Burt SE, Cole LL, Fairfield-Estill C, Fine $L$, et al. Musculoskeletal disorders and workplace factors. National Institute for Occupational Safety and Health (NIOSH). 1997:104.

23. Vieira ER, Kumar S. Cut-points to prevent low back injury due to force exertion at work. Work. 2006;27(1):75-87.

24. Kim YS, Rhee KY, Oh MJ, Park J. The validity and reliability of the second korean working conditions survey. Saf Health Work. 2013;4(2):111-6.

25. Choi ES, Kwon MJ, Lee HJ, Cho GY. The association between psychosocial work environment and depressive symptoms among Korean teachers. J Korean Acad Community Health Nurs. 2017;28(4):463-71.

26. Lipscomb JA, Trinkoff AM, Geiger-Brown J, Brady B. Work-schedule characteristics and reported musculoskeletal disorders of registered nurses. Scand J Work Environ Health. 2002;28(6):394-401.

27. Burdorf A, Sorock G. Positive and negative evidence of risk factors for back disorders. Scand J Work Environ Health. 1997;23(4):243-56.

28. Roffey DM, Wai EK, Bishop P, Kwon BK, Dagenais S. Causal assessment of awkward occupational postures and low back pain: results of a systematic review. Spine J. 2010;10(1):89-99. https://doi.org/10.1016/j.spinee.2009.09.003.

29. Yassi A, Khokhar J, Tate R, Cooper J, Snow C, Vallentyne S. The epidemiology of back injuries in nurses at a large Canadian tertiary care hospital: implications for prevention. Occup Med (Lond). 1995;45(4):215-20.

30. Marras WS, Davis KG, Kirking BC, Bertsche PK. A comprehensive analysis of low-back disorder risk and spinal loading during the transferring and repositioning of patients using different techniques. Ergonomics. 1999;42(7): 904-26

31. Pompeii LA, Lipscomb HJ, Schoenfisch AL, Dement JM. Musculoskeletal injuries resulting from patient handling tasks among hospital workers. Am J Ind Med. 2009:52(7):571-8.

32. Vandergrift JL, Gold JE, Hanlon A, Punnett L. Physical and psychosocial ergonomic risk factors for low back pain in automobile manufacturing workers. Occup Environ Med. 2012;69(1):29-34.

33. David GC. Ergonomic methods for assessing exposure to risk factors for workrelated musculoskeletal disorders. Occup Med (Lond). 2005;55(3):190-9.

34. Mozafari A, Vahedian M, Mohebi S, Najafi M. Work-related musculoskeletal disorders in truck drivers and official workers. Acta Med Iran. 2015;53(7):432-8.

35. Croker MJ, editor. Handbook of noise and vibration control. Hoboken NJ: John Wiley \& Sons; 2007.

36. Lee $\mathrm{S}$, Lee W, Roh J, Won JU, Yoon JH. Symptoms of nervous system related disorders among workers exposed to occupational noise and vibration in Korea. J Occup Environ Med. 2017:59(2):191-7.

37. Kivimäki M, Vahtera J, Ferrie JE, Hemingway H, Pentti J. Organisational downsizing and musculoskeletal problems in employees: a prospective study. Occup Environ Med. 2001;58(12):811-7.
38. Bongers PM, Kremer AM, ter Laak J. Are psychosocial factors, risk factors for symptoms and signs of the shoulder, elbow, or hand/wrist?: a review of the epidemiological literature. Am J Ind Med. 2002;41(5):315-42.

39. Feuerstein $M$, Harrington CB, Lopez $M$, Haufler A. How do job stress and ergonomic factors impact clinic visits in acute low back pain? A prospective study. J Occup Environ Med. 2006:48(6):607-14.

\section{Ready to submit your research? Choose BMC and benefit from:}

- fast, convenient online submission

- thorough peer review by experienced researchers in your field

- rapid publication on acceptance

- support for research data, including large and complex data types

- gold Open Access which fosters wider collaboration and increased citations

- maximum visibility for your research: over $100 \mathrm{M}$ website views per year

At BMC, research is always in progress.

Learn more biomedcentral.com/submissions 